\title{
THE ASIAN DEVELOPMENT BANK ADMINISTRATIVE TRIBUNAL: CONSTITUTIVE INSTRUMENTS AND CASE-LAW
}

\author{
Raul C. Pangalangan*
}

\section{INTERNATIONAL ADMINISTRATIVE TRIBUNALS IN THE CONTEXT OF INTERNATIONAL LAW}

International organizations have established administrative tribunals to address unique dilemmas deriving from their institutional independence and international character. The law governing the institutional life of such an organization cannot be the municipal legal system of its members or of its host government, ${ }^{1}$ and can only be drawn from its constituent charter as interpreted in light of general principles of international law. Moreover, in order to ensure the political independence of the organization and its staff members as international civil servants, ${ }^{2}$ these charters contain jurisdictional immunities which place the organization beyond the reach of the courts of the municipal legal order of its member states. ${ }^{3}$

\footnotetext{
* University of the Philippines, Manila; Asian Development Bank Administrative Tribunal. The views expressed here are the author's alone and do not represent the official views of the Tribunal.

' C.F. Amerasinghe, Principles of the institutional law of international organizations (1996) at 13.

${ }^{2}$ See Reparations for Injuries Suffered in the Service of the United Nations, ICJ Rep.1950: 4. But see Application for Review of Judgment No. 333 of the United Nations Administrative Tribunal [Yakimetz case], ICJ Rep.1987:18: this involved the practice of the then USSR and other socialist countries whose nationals (apparently until 1988) could only be seconded from the national governments, reflecting their "scepticism of the concept of an impartial and objective international civil service". A.ALI, "The international civil service: the idea and the reality", in C.DE COOKER (ed.), International Administration: Law and Management Practices in International Organizations, I.1. The Court ruled that the person being on loan from a government, it was necessary to secure the consent of that government.

${ }^{3}$ See, for instance, Agreement Establishing the Asian Development Bank (hereinafter: the ADB Charter), Art.50 ("Immunity from Judicial Proceedings") and Art.55 ("Immunities and Privileges of Bank Personnel"), and Agreement between the Asian Development Bank and the Government of the Republic of the Philippines Regarding the Headquarters of the Asian Development Bank (hereinafter: the Headquarters Agreement), Art.III ("Immunity from Judicial Proceedings") and Art.XII ("Privileges and Immunities ...").
}

Asian Yearbook of International Law, Volume 7 (Ko Swan Sik et al., eds.

${ }^{\circ}$ Kluwer Law International; printed in the Netherlands), pp. 209-228 
Institutional independence, therefore, diminishes the recourse by international civil servants to the usual legal devices for protecting their rights. Referring to the United Nations Administrative Tribunal ${ }^{4}$ it was stated:

"Because of the immunity of these international organizations from the jurisdiction of the courts of their member States, the only way of giving staff members any form of judicial redress for complaints that they may have against the organizations arising out of their terms of employment has been by creating a special internal tribunal - the UN Administrative Tribunal." 5

Without administrative tribunals, disputes between international civil servants and their employer organizations would be settled, not by judicial means, but through administrative decision by an executive organ. Management decisions were thus final because unappealable, and aggrieved staff did not have recourse to any impartial appeal mechanism. ${ }^{6}$ The World Court acknowledged this in the Effects of Awards case, which upheld the power of the UN Tribunal to grant relief in the form of compensation:

"In the absence of ... an Administrative Tribunal, the function of resolving disputes between staff and Organization could be discharged by the Secretary General .... Accordingly, in the three years or more preceding the establishment of the Administrative Tribunal, the Secretary General coped with this problem by means of joint administrative machinery, leading to ultimate decision by himself. "7

Indeed, in the case of the World Bank Administrative Tribunal (hereinafter, the WB Tribunal), it was explained that without such a tribunal, national courts might assert jurisdiction over complaints against the bank by staff members, undermining the international character of the bank and its staff. ${ }^{8}$ Indeed, it was explained that the World Bank created its own tribunal instead of submitting to the jurisdiction of extant administrative tribunals (e.g., the UN Tribunal) in

\footnotetext{
${ }^{4}$ Hereinafter: UN Tribunal. Statute of the United Nations Administrative Tribunal, UNGA Resolution 351(IV), 24 November 1949, as amended by UNGA Resolution 957(X), 8 November 1955 .

${ }^{5}$ E. LAUTERPACHT, Aspects of the Administration of International Justice (1991) 106-7.

${ }^{6}$ AMERASINGHE, op.cit.n. 1 at 446.

${ }^{7}$ Effects of Awards of Compensation Made by the United Nations Administrative Tribunal, adv.op.13 July 1954, ICJ Rep.1954: 61. The UN and ILO tribunals have, through their respective statutes, submitted to review under the advisory jurisdiction of the ICJ (UNAT Statute, Art.11; ILO Statute, Art.12; ICJ Statute, Art.65(1). See T.O. EliAS, The International Court of Justice in relation to the Administrative Tribunals of the United Nations and the International Labour Organisation, in DE COOKER, op.cit.n.2 at V.4.

${ }^{8}$ C.F. AMERASINGHE, "The World Bank Administrative Tribunal: its establishment and its work", in DE COOKER, op.cit.n.2 at V.3/2-3, citing memorandum from the World Bank President to the Executive Directors, dated 14 January 1980.
} 
order "to maintain its independence ... from organizations that were increasingly being subjected to some degree of politicization". ${ }^{9}$

International organizations thus create their respective courts under their charters, and voluntarily submit to the jurisdiction of those courts. The International Labour Organisation ${ }^{10}$ established its administrative tribunal in 1946; the United Nations, in 1949; the World Bank ${ }^{11}$ and the Inter-American Development Bank, ${ }^{12}$ both in 1981; the Asian Development Bank, ${ }^{13}$ in 1991; and the International Monetary Fund, in 1992. ${ }^{14}$ The International Court of Justice has rendered advisory opinions reviewing decisions by those administrative tribunals whose statutes provide for such review. ${ }^{15}$

These tribunals usually have been created even without express authority under the constituent charter of the organization. Although the Preparatory Commission of the United Nations had expressly recognized the possibility of creating an administrative tribunal patterned after that of the League of $\mathrm{Na}$ tions, ${ }^{16}$ the establishment of the UN Tribunal was in fact challenged before the World Court, on the ground, inter alia, that the General Assembly could not have created a subordinate body capable of binding the Assembly itself. In the Effects of Awards case (supra, text at n.7) the World Court recognized that the power of the United Nations to establish an internal court, "though not expressly provided in the constituent instrument, were conferred upon [the organization] by necessary implication as being essential to the performance of its duties" 17 and thus arose "by necessary intendment out of the Charter" ${ }^{18}$ The Court continued:

${ }^{9}$ C.F. AmERASINGHE, Documents on International Administrative Tribunals (1989) at 44.

${ }^{10}$ Statute of the Administrative Tribunal of the International Labour Organisation, 9 October 1946, as amended on 29 June 1949 and 17 June 1986.

"Statute of the Administrative Tribunal of the International Bank for Reconstruction and Development, International Development Association, and International Finance Corporation, 1 July 1980.

${ }^{12}$ Statute of the Inter-American Development Bank Administrative Tribunal, April 1981 as amended in November 1981 and March 1984.

${ }^{13}$ Statute of the Administrative Tribunal of the Asian Development Bank (hereinafter ADB Tribunal Statute), 1 April 1991, as amended 1 January 1995, in 1 ADBAT Rep.(1998) 99 and 2 ADBAT Rep.(1998) 191.

${ }^{14}$ Statute of the Administrative Tribunal of the International Monetary Fund, 15 October 1992.

${ }^{15}$ In addition to the advisory opinions already cited, the fourth and most recent is Application for Review of Judgment No. 273 of the United Nations Administrative Tribunal [Mortished case], Advisory Opinion of 20 July 1982, 1982 ICJ Rep.325. Recourse to the ICJ is provided for only in the Statutes of the UN and the ILO Tribunals. However, the UN General Assembly has decided, by resolution dated 11 December 1995, to amend Art.11 of the UN Tribunal Statute, and limit recourse to the ICJ for cases delivered as from 1 January 1996. (The International Court of Justice, 4th ed.(1996) at 86-87.

${ }^{16}$ GUTTERIDGE, "The ILO Administrative Tribunal", in DE COOKER, op.cit.n.2 at V.2/2.

${ }^{17}$ AMERASINGHE, op.cit.n. 1 at 449.

${ }^{18}$ Effects of Awards of Compensation Made by the United Nations Administrative Tribunal, adv.op. 13 July 1954, ICJ Rep.1954: 47. 
"[T]he Tribunal is established [...] not as an advisory organ or a mere subordinate committee of the General Assembly, but as an independent and truly judicial body pronouncing final judgments without appeal within the limited field of its functions. [Its] judgment[s are] res judicata and ha[ve] binding force between the parties to the dispute. .... As this final judgment has binding force on the United Nations Organization as the juridical person responsible for the proper observance of the contract of service, that Organization becomes legally bound to carry out the judgment and to pay the compensation awarded to the staff member." 19

The result is the international administrative tribunal, whose jurisdiction is 'novel' ${ }^{20}$ in international law:

"Individuals, international organizations and states have been parties in controversies brought before the[se] tribunals; public international contracts, staff rules and regulations unilaterally issued by international organizations and multilateral treaties have been construed by the judges of these institutions. "21

The World Court has noted the international character of international administrative proceedings, notwithstanding that they deal with disputes, not between states, but between an individual and an international organization. Its advisory opinion was sought to review a decision by the International Labour Organisation Administrative Tribunal (hereinafter, the ILO Tribunal), upholding the termination of four staff members by the UNESCO, which had submitted to the jurisdiction of the ILO Tribunal. Significantly, the dissenting opinions highlighted the difficulty inherent in the inequality between individual grievants and the international organization, i.e., that despite the contentious character of the dispute, the grievants could not present their case directly to the Court but rather through statements submitted to the international organization entitled to seek an advisory opinion. ${ }^{22}$

\footnotetext{
${ }^{19}$ Ibid. at 53.

${ }^{20}$ A. SCHECHTER, Interpretation of ambiguous documents by international administrative tribunals (1964) at 3.

${ }^{21}$ Ibid. at 126-27.

${ }^{22}$ The advisory jurisdiction of the Court is limited to requests by public international organizations (ICJ Statute, Chapter IV). See also Judgments of the Administrative Tribunal of the ILO Upon Complaints Made Against UNESCO, adv.op.23 Oct.1956, ICJ Rep.1956:77; Application for Review of Judgment No. 158 of the United Nations Administrative Tribunal, adv.op.12 July 1973 [Fasla], ICJ Rep.1973:166 (the Court's advisory jurisdiction can be exercised in cases relating to proceedings before other tribunals wherein individuals were parties).
} 


\section{THE ADB TRIBUNAL: CONSTITUTIVE INSTRUMENTS AND BRIEF HISTORY}

\subsection{The ADB as an international organization}

The ADB is a multilateral institution, with headquarters in Manila, Philippines, which serves as the regional development bank in Asia and the Pacific. It is governed by a charter establishing the Bank in 1966, and is run by a Board of Governors, comprising representatives of all its Member Countries who meet annually ${ }^{23}$ and a Board of Directors, elected by the Governors, "responsible for the direction of the general operations of the Bank" ${ }^{24}$ The President is the "chief of the staff of the Bank" and is responsible for the "organization, appointment and dismissal of the officers and staff". ${ }^{25}$ The political neutrality of the institution and its staff is secured through the "Prohibition of Political Activity: The International Character of the Bank", which states:

"2. The Bank, its ... officers and staff shall not interfere in the political affairs of any member, nor shall they be influenced in their decisions by the political character of the member concerned. Only economic considerations shall be weighed impartially in order to achieve and carry out the purpose and functions of the Bank.

3. The President, Vice-President(s), officers and staff of the Bank, in the discharge of their offices, owe their duty entirely to the Bank and to no other authority. Each member [state] of the Bank shall respect the international character of this duty ...." ${ }^{26}$

Its charter further provides that the Bank as an institution shall enjoy 'immunities, exemptions and privileges' in the territory of each member state. The Bank is thus immune from the jurisdiction of the courts and government agencies of its member states. ${ }^{27}$ This immunity is further strengthened by its Headquarters Agreement with the host state, the Philippines, which provides for 'immunity from judicial proceedings' ${ }^{28}$

Of its current ${ }^{29} 1,924$ staff members, 645 are professional staff, while 1,279 are support staff (of whom 1,133 are Filipino). The professional staff are geographically distributed, and consist of various nationalities; the support staff, however, are predominantly of Philippine nationality. Staff members are

\footnotetext{
${ }^{23}$ ADB Charter Arts.27-29.

${ }^{24}$ ADB Charter Arts. 30-33.

${ }^{25}$ ADB Charter Art.34.

${ }^{26}$ ADB Charter Art.36.

${ }^{27}$ ADB Charter, Chapter VIII ("Status, Immunities, Exemptions and Privileges").

${ }^{28}$ Headquarters Agreement Art.III. See Bares, Decision No.5 [1995], 1 ADBAT Rep.53, 55, recognizing that ADB is immune from suit in national courts; Department of Foreign Affairs $v$. National Labor Relations Commission (G.R. No.113191, 18 Sep.1996), upholding the ADB's immunity from legal process under the Headquarters Agreement.

${ }^{29}$ As of August 1999.
} 
organized in a single employees' organization, the Staff Council. The rights and benefits of staff are contained in Staff Rules issued by the Board of Directors and in administrative orders and circulars issued by management.

\subsection{The Statute and Rules of Procedure of the ADB Tribunal}

In 1990, the ADB adopted a Personnel Policy Statement ${ }^{30}$ setting forth the fundamental principles governing its personnel, including the observance of "due process in all areas of personnel administration". ${ }^{31}$ The Statement specifically referred to an Administrative Tribunal:

"Where grievances arise, staff will be entitled to invoke administrative review as well as the grievance and appeals procedres, without fear of reprisal, including ultimate recourse to an Administrative Tribunal whose decision shall be binding on the Bank and the staff. ${ }^{32}$

The Tribunal was established in April 1991. Until then, disputes on the interpretation of staff rights and benefits were decided by internal grievance machinery, culminating with an Appeals Committee comprised of fellow staff members designated by Management and the Staff Council. ${ }^{33}$ With the creation of the Tribunal, decisions by Management were subject of judicial review by a panel of external judges.

Following similar process in other international organizations, the ADB Board of Directors created the Tribunal through a 'Statute' ${ }^{34}$ which set out the Tribunal's jurisdiction, composition and basic procedure. To preserve and maintain the independence of the Tribunal, the judges function independently under this Statute. Indeed, although the judges are appointed by the Board of Directors, the list of candidates is drawn up by the President only after consultation with the Staff Council. ${ }^{35}$

The original Statute provided for three members, appointed for a term of three years and who were to select a chairman from amongst them. ${ }^{36}$ The judges were to be "persons of high moral character and [who] possess the qualifications required for appointment to high judicial office or [are] juriscon-

\footnotetext{
${ }^{30}$ Approved by the Board of Directors on 7 December 1990, see Personnel Handbook for Professional Staff and Personnel Handbook for Supporting Staff.

${ }^{31}$ Ibid. para. xiii.

${ }^{32}$ Ibid. para. xi.

${ }^{33}$ Administrative Order No.2.06, Grievance and Appeal Procedures, issued 23 September 1987.

${ }^{34}$ Statute of the Asian Development Bank Administrative Tribunal, 1 ADBAT Rep., Appendix I, at 99 .

${ }^{35}$ Ibid. Art.IV para.2.

${ }^{36}$ Ibid. Arts.IV and V.
} 
sults of recognized competence". ${ }^{37}$ The Statute also provided for an Executive Secretary to assist the Tribunal in preparing the cases for decision and "who, in the discharge of duties, shall be responsible only to the Tribunal" ${ }^{38}$ The Tribunal has usually met twice a year at the Philippine headquarters of the ADB, although it has also met outside the Philippines as allowed in its Statute. ${ }^{39}$ The Rules of Procedure, adopted by the Tribunal pursuant to the Statute, ${ }^{40}$ took effect on 1 January 1992.

The Tribunal has decided 44 cases since it was established. These cases are published in its own Reports, published by the office of the Executive Secretary. There are now four volumes of the Reports: Volume I covers the years 1991 to 1995 and includes all the decisions rendered by the first set of judges; it also contains the original Statute (April 1991) and Rules of Procedure (December 1991). Volume II covers the year 1996, and contains as well the revised Statute (revised 22 December 1994, effective 1 January 1995) and Rules of Procedure (revised, effective 1 January 1992 and amended up to 10 August 1995). Volume III and IV cover, respectively, the years 1997 and 1998.

\subsection{Historical survey: the Judges, revisions of the Statute and the Rules, and case highlights}

The first set of judges sat on the Tribunal from 1991 to 1995. Professor ELIHU LAUTERPACHT, CBE, QC, then Director of the Research Centre of the University of Cambridge (later also President of the World Bank Administrative Tribunal and currently Judge ad hoc before the International Court of Justice in the Genocide Case involving the former Yugoslavia), was elected Chairman of the Tribunal. The other judges were Philippine Supreme Court Justice FloRENTINO FELICIANO (now judge of the Appellate Body of the World Trade Organization in Geneva), and Sri Lankan Supreme Court Justice MARK D. H. FERNANDO (now also judge at the ILO Tribunal).

The Tribunal rendered its first judgment in December 1992, holding that the applicant's separation from the Bank, with the expiration of his initial fixedterm appointment, was defective due to procedural unfairness. The Tribunal held, notwithstanding that a fixed-term appointee has no right to the renewal of his contract, that he was entitled to procedural fairness in the process leading to the decision whether or not to renew that contract. The Tribunal, citing precedent from the WB Tribunal, also read its remedial powers to include - not just

\footnotetext{
${ }^{37}$ Ibid. Art.IV para.1.

${ }^{38}$ Ibid. Art.IV para.V para.2.

${ }^{39}$ Ibid. Art.VII ("taking into account the need for the efficient and cost-effective conduct of the proceedings as well as for providing the opportunity for full and fair hearings").

${ }^{40}$ Ibid. Art.VI.
} 
a choice among rescission of the contested decision, specific performance or, in its place, compensation - the power to grant compensation for injury caused. ${ }^{41}$

At the following session, held in January 1994, the Tribunal resolved its first performance evaluation (PER) case and found that the staff member's PER scores did not reflect his true rating due to an informal quota of 'distinguished' ratings. The Tribunal also laid down the guiding principle by which it will review management decisions that are discretionary in character. Such power of judicial review was triggered the moment these decisions had an "effect upon the position of staff members in their individual relationships with the Bank". The applicable test was whether such decisions had been "arbitrary, discriminatory or improperly motivated, or have been carried out in violation of a fair and reasonable procedure" ${ }^{42}$ The Tribunal also decided the first of its four tax reimbursement decisions, all brought by the same applicants, one American and one Filipino. They were subjected to income taxation by their respective states of nationality, which, through treaty reservations at the time of ratification, had taken themselves out of the ADB Charter's tax immunity clauses. The Tribunal upheld their claim that the Bank's express guarantee of equal treatment entailed an obligation to equalize the salaries paid them, i.e., through tax reimbursements. ${ }^{43}$

In 1995, the Tribunal decided a most dramatic case arising from the murder of a ranking lawyer of the Bank in its own basement parking area, in the hands of a member of its own security contingent. A Philippine court had found that the security guard was guilty of fatally stabbing the victim. The family sued the Bank for compensation before the Tribunal. The Tribunal, finding that the claim was founded on contract and not on vicarious liability arising from tort, held that any supposed defects in the Bank's security system could not have prevented the tragic event, and that the Bank had met its duty to exercise reasonable care to ensure the safety of its staff members. The Tribunal nonetheless recommended, in a 'Rider' to its judgment, an ex gratia payment to the widow and children of the victim, considering that otherwise they would be in the same financial position as if the victim had not died under such extraordinary circumstances. ${ }^{44}$

The Bank amended the Statute in 1995, increasing the membership of the Tribunal from three to five members, providing for hearings by panels of three, and expressly providing for the recording of dissenting opinions ${ }^{45}$ With the resignation of judges LAUTERPACHT and FELICIANO, four new members were appointed: Professor BRIGITTE STERN of the University of Paris I, Dr. LAXMI SINGHVI who was India's High Commissioner to London, Professor

\footnotetext{
${ }^{41}$ Lindsey, Decision No. 1 [1992], 1 ADBAT Rep. 1.

${ }^{42}$ Tay Sin Yan, Decision No. 3 [1994], 1 ADBAT Rep. 35.

${ }^{43}$ Mesch and Siy, Decision No. 2 [1994], 1 ADBAT Rep. 21.

${ }^{44}$ Bares et al., Decision No. 5 [1995], 1 ADBAT Rep. 53.

${ }^{45}$ Statute of the Asian Development Bank Administrative Tribunal (as amended on 22 December 1994, effective 1 January 1995), 5 ADBAT Rep., Appendix I, at 191.
} 
Toshio SAWADA of Sophia University, and Professor RoBERT GoRMAN of the University of Pennsylvania Law School and one of the founding judges of the WB Tribunal. With the increase in membership, the Tribunal was to be headed by a President and a Vice-President. Justice FERNANDO, the remaining member, was elected President, and Professor GoRMAN was elected Vice-President.

Among the highlights of the work of the 'new' Tribunal are the following: the first case filed by a member of the supporting staff (who won his claim against what he felt was an unfair PER rating), ${ }^{46}$ and the first disciplinary cases appealed to the Tribunal (finding that investigative process met the essential due process requirements). ${ }^{47}$ In a case of a member of the supporting staff who was kept by the Bank on renewed one-year contracts for more than twelve years and was 'regularized' only two years before his mandatory retirement. The Tribunal set aside these contracts as not reflecting the true intent of the parties, deemed the increased the retirement benefits to. The Tribunal held that the use of short-term contracts which denied him benefits was a détournement de pouvoir or abuse of power, and set aside the one-year contracts as not reflecting the true relationship between the Bank and the staff member. ${ }^{48}$ Finally, the Tribunal also upheld the exclusion of certain staff members from what they claimed was a generous early retirement program. ${ }^{49}$

In light of the new provisions of the Statute, the Tribunal also had its first dissenting opinions, both by Professor BRIGITTE STERN and, in the second, with Professor SAWADA joining the dissent. In a case where the Tribunal upheld the mandatory retirement age of 60 set forth in administrative orders, Professor STERN found that the age of retirement of 65 fixed in the Staff Regulations issued by the Board in 1966 remained valid and could not have been validly revised by internal practice, memoranda or other issuances by management. ${ }^{50}$ In the last of the tax reimbursement cases, the same claimants challenged the decision by the Board of Directors, subsequent to the Tribunal's decision, expressly prohibited such payments following the Tribunal's earlier decision. Professor STERN contended that the Board may not do so unless it likewise disavowed or expressly abandoned the principle of equal pay for equal work internally and externally. ${ }^{51}$

New judges have since been appointed to the Tribunal, two in 1996 and one in 1997. Professor STERN was replaced by Professor MARTTI KoSKENNIEMI of the University of Helsinki, Dr. SinGHVI, by Dr. THIO SU MIEN, former law dean and private practitioner in Singapore; and Professor SAWADA, by Professor SHINYA MURASE, likewise of Sophia University.

\footnotetext{
${ }^{46}$ Isip, Decision No. 9 [1996], 2 ADBAT Rep. 1.

${ }^{47}$ Zaidi, Decision No. 17 [1996], 2 ADBAT Rep. 89; Chaudhry, Decision No. 23 [1996], 2 ADBAT Rep. 171.

${ }^{48}$ Amora, Decision No. 24 [1997], 3 ADBAT Rep. 1.

${ }^{49}$ Breckner, Decision No. 25 [1997], 3 ADBAT Rep. 25.

${ }^{50}$ Samuel (No. 2), Decision No. 15 [1996], 2 ADBAT Rep. 51; STERN, dissenting, at 69.

${ }^{51}$ Mesch and Siy (No. 4), Decision No. 35 [1997], 3 ADBAT Rep. 71; STERN and SAWADA, dissenting, at 93.
} 
The Tribunal recently rendered two decisions interpreting the principle of equal treatment. The first involved the claim by forty Filipino professional staff against the exclusion of Filipinos from the full enjoyment of certain benefits extended to other similarly situated staff; their claim was upheld as regards two benefits, force majeure protection and education grants, but rejected as regards two other benefits, home leave and separation pay). ${ }^{52}$ The second involved the claim of a woman professional staff member that her separation from the Bank was due, inter alia, to gender-based discrimination; the gender claim was thrown out, though the Tribunal did find some procedural defects in the Bank's decision. ${ }^{53}$

\section{CASE-LAW OF THE ADB TRIBUNAL}

An author, reviewing the early work of international administrative tribunals, noted the "near total absence of citation to the authority of prior decisions of the same court or judgments of other courts" 54 and a general tendency thus to treat each case as unique. ${ }^{55} \mathrm{He}$ also noted the readiness of these tribunals to interpret documents even absent any ambiguity, contrary to the usual rule of intepretation and, more specifically, the 'clear-meaning' doctrine, ${ }^{56}$ and to seek recourse to the travaux preparatoires and the intent of the parties. ${ }^{57}$

This section surveys the points of law established by the Tribunal in its case-law. It is limited however to questions relevant to public international law, and thus excludes the more specific points, of personnel practice, for instance, that are of interest only internally to the Bank's own staff.

\subsection{Sources of Law}

While the applicable law can be variously characterized, e.g., as a distinct part sui generis of international law, as the 'internal law' of the organization, or as mere contract, it has been characterized as part of international law in its aspect as the emanation of the constituent treaty establishing the organization, from which the power to legislate the internal law is derived. "The [constituent] treaty itself is international law and, therefore, generates international law". ${ }^{58}$

\footnotetext{
${ }^{52}$ De Armas et al., Decision No. 39 [1998], 4 ADBAT Rep. 9.

${ }^{53}$ Alexander, Decision No. 40 [1998], 4 ADBAT Rep. 41.

${ }^{54}$ SCHECHTER, op.cit.n.21.

${ }^{55}$ Ibid. at 110.

${ }^{56}$ Ibid. at 130.

${ }^{57}$ Ibid. at 132-33.

${ }^{58}$ AMERASINGHE, op.cit.n.1 at 326.
} 


\subsubsection{General Matters}

\subsubsection{Nature of the ADB Tribunal}

"The Tribunal is not akin to one of general jurisdiction within the national sphere. Here the proceedings are controlled entirely by the Statute ..." ${ }^{59}$ As stated above (supra p. 216), there was the tragic killing in the Bank's headquarters of one of its counsels by a member of its own security contingent. ${ }^{60}$ The victim's family thereupon sued the Bank for compensation. From the outset, the Tribunal declined to treat the claim as one founded on the law of tort, i.e., the Bank's vicarious liability for injuries caused by its staff, which may have otherwise prospered in a national court for which, however, the Bank was immune. The Tribunal recognized

"the theoretical possibility that the parties might have agreed to resort to this Tribunal not as the Administrative Tribunal of the Bank subject to its Statute but as a group of individuals who, though happening to be the Members of the Tribunal, have agreed, at the request and with the consent of the parties and, for the purpose of the particular proceedings, to act as a special tribunal or arbitral body outside the scope of the Tribunal's Statute."

The case having been brought under the Statute, the Tribunal's jurisdiction was thus limited to the Bank's contractual liability to its staff, and the Tribunal found that the Bank had not been negligent.

Flowing from this strict adherence to the contractual scope of its jurisdiction, the Tribunal declined to apply the international law relating to the responsibility of states for the wrongful acts of officials causing injury to aliens:

"The Tribunal is not authorized to assess the international responsibility, tortious or otherwise, of an international organization on the plane of public international law, especially at the instance not of another person of comparable international standing, but rather upon the initiative of an aggrieved individual." 61

\subsubsection{Sources in general}

The Tribunal identified the following as the 'principal rules of law' which provide the 'framework' for its decisions: the constitutive instruments of the Bank and of the Tribunal; general principles of law; the employment contract; staff rules and regulations, including administrative issuances; the Personnel Handbooks issued to staff; and 'by analogy', staff practices of other international organizations, including the decisions of international administrative tri-

\footnotetext{
${ }^{59}$ Bares, Decision No.5 [1995], 1 ADBAT Rep. 53, 55.

${ }^{60}$ People v. Fernando Macalindong, Criminal Case No.91164, slip op., Regional Trial Court, Branch 156, Pasig, Metro Manila, Philippines.

${ }^{61}$ Bares, Decision No.5 [1995], 1 ADBAT Rep. 53, 57, 65.
} 
bunals. The Tribunal also referred to a 'common' law of international organizations and to 'acquired rights' of staff. ${ }^{62}$

\title{
3.1.2. Specific sources
}

\subsubsection{Fundamental and essential conditions of employment}

The Tribunal affirmed that while the Bank had the power unilaterally to change the conditions of employment of staff, certain elements are "fundamental and essential in the balance of rights and duties of the staff member [and] are not open to any change without the consent of the staff member affected". 63

\begin{abstract}
"Although some terms and conditions of employment can be prospectively altered, the principle that fundamental and essential terms and conditions of employment cannot unilaterally be amended is now a recognized principle which can be regarded as part of the law common to international organizations. That principle imposes a limitation on the powers of the governing bodies of every international organization, restraining the unilateral amendment of such terms and conditions. ${ }^{.64}$
\end{abstract}

The Tribunal had earlier found that the Bank's declaration of equal treatment of all staff meant, absent any qualification, that the Bank should reimburse the taxes paid by staff (in this case, one American and one Filipino), whose national governments taxed ADB income unlike other ADB member governments which had waived their power to tax. The Bank subsequently adopted a resolution "reaffirm[ing] its long-standing practice of non reimbursement" and declaring that henceforth, its obligation of equal treatment shall be interpreted to apply to before-tax salaries. ${ }^{65}$ The two staff members returned to the Tribunal and challenged this resolution as a unilateral amendment of a fundamental and essential condition of employment. The Tribunal upheld the resolution, holding that the right to tax reimbursement was not a fundamental and essential condition of employment: ${ }^{66}$

"Fundamental terms are of two kinds. [The first are terms which] are so basic that they will always be implied, and perhaps are not even capable of express waiver save in extraordinary circumstances ....

[The second are terms] which are not intrinsically fundamental, but may become so if the parties so intend. ${ }^{67}$

\footnotetext{
${ }^{62}$ Lindsey, Decision No.1 [1992], 1 ADBAT Rep. 1, 2.

${ }^{63}$ Mesch \& Siy (No. 3), Decision No.18 [1996], 2 ADBAT Rep.117, 125.

${ }^{64}$ Ibid. 117, 126.

${ }^{65}$ Mesch and Siy (No. 2), Decision No.6 [1994], 1 ADBAT Rep.21.

${ }^{66}$ Mesch and Siy (No. 4), Decision No. 35 [1997], 3 ADBAT Rep. 71.

${ }^{67}$ Ibid., at 80-81.
} 
Examples of the first kind are the following:

\begin{abstract}
"that an employee must be paid for his services, that he is entitled to a weekly holiday and to leave, that due process must be observed before he is dismissed, and that on matters of remuneration, employees are entitled to a fair wage, one that assures "equal remuneration for work of equal value", and one that does not discriminate between men and women. "68
\end{abstract}

Examples of the second are rights which are 'acquired' when they are embodied either in the Staff Regulations or rules and are "of decisive importance to a candidate for appointment", or in the contract of appointment "and both parties intend that [these] should be inviolate." 69

The Tribunal found that these conditions had not been satisfied. Since the Bank's formation, there had been no "pattern or practice of making such reimbursement, let alone one that [was] clear, unambiguous, consistent, and of significant duration". Staff members could thus not have reasonably assumed tax reimbursement to be 'central to their contract', or to be of 'decisive importance to them' ${ }^{70}$

A dissenting opinion objected to the majority's view that some rights are fundamental per se while other rights "may become fundamental when the parties so agree". Citing the World Bank Tribunal's reasoning in De Merode, the dissenting opinion contended that the 'expectations of the parties' is not a workable criterion because in any contract there are at least two subjective intentions, two conflicting intents. ${ }^{71}$ The dissent contended that the principle of equal pay for equal work has been recognized by both parties and by the Tribunal as a fundamental and essential term of employment. Since this entails both 'formal' and 'effective' equality, it is thus 'inseparable' from the principle of tax reimbursement. The "equalization of remuneration ... whether through tax reimbursement or any other system to the same effect - is inherent to this principle". ${ }^{72}$

\title{
3.1.2.2. Contract of employment
}

The Bank's staff comprises tenured, regular employees and untenured contractual employees. ${ }^{73}$ In a case wherein a person was kept on one-year contracts for thirteen years and was 'regularized' just about 3 years prior to retirement, the Tribunal held that the contracts did not "correctly reflect the true relation-

\footnotetext{
${ }^{68}$ Ibid. at 80 .

${ }^{69}$ Ibid. at 81 .

${ }^{70}$ Ibid. at 82 .

${ }^{71}$ Ibid. (STERN dissenting) 71, 100.

${ }^{72}$ Ibid. STERN dissenting, at 93.

${ }^{73}$ Administrative Order No.2.01, Recruitment and Appointment, revised 9 July 1998.
} 
ship" between the parties, and that the intent of the parties as manifested in the contracts was that the relationship was that of employer and employee: ${ }^{74}$

"[R]ecourse to successive short-term or temporary contractual appointments to jobs which are essentially of a permanent nature is not a fair employment practice, particularly if such appointments can be shown to have been made only to deny employees security of tenure or other conditions and benefits of service. ${ }^{175}$

\subsubsection{Practice by other international organizations}

Some aspects of fair procedure, for instance, were found to be a "widespread practice" that can qualify as "a general practice accepted as law" ${ }^{76} \mathrm{~A}$ dissenting opinion in one of the landmark tax reimbursement cases likewise cites "the generally accepted practice of the overwhelming majority of international organizations" and "precedents of international administrative tribunals". ${ }^{77}$

\subsubsection{Interpretation}

"In any community, including the workplace, something more than what is legally correct is desirable." A woman working as a secretary in the Bank filed a complaint before a Philippine court for slanderous utterances by her supervisor, who was arrested but no sooner released because of his immunities as a staff member of an international organization. While the case was pending, the Bank conducted its yearly performance evaluation of staff, and this supervisor, together with other staff who supervised the secretary, evaluated the secretary, who subsequently complained about her negative rating. The Tribunal held that the supervisor who was sued and briefly jailed could not have possibly possessed the requisite neutrality and impartiality called for in such an evaluation exercise, and that the consequent rating was thus defective. ${ }^{78}$

In the tax reimbursement case cited above, the Tribunal stated:

"In balancing ... the equities as between the Bank and its staff, the Tribunal considers that more weight should be given to the interests of the employee than to those of the employer, if only because the Bank could have so structured its terms of employment as to exclude expressly the prospect of equal pay for comparable work and could thus have excluded the need for tax reimbursement. But it never did so. Any ambiguity or uncertainty in this respect,

\footnotetext{
${ }^{74}$ Amora, Decision No.24 [1997], 3 ADBAT Rep.1, 7.

${ }^{75}$ Ibid.

${ }^{76}$ Lindsey, Decision No.1 [1992], 1 ADBAT Rep.1, 3.

${ }^{77}$ Mesch and Siy (No. 4), STERN dissenting, Decision No.35 [1997], 3 ADBAT Rep.71, 106.

${ }^{78}$ Cabal, Decision No.22 [1996], 2 ADBAT Rep.163, 167.
} 
wherever appearing in documents emanating from the Bank must, therefore, be resolved contra preferentem and in favor of the staff. ${ }^{179}$

And in its first decision, the Tribunal, noting that the due process guarantees were not expressly incorporated in the Bank's rules until the Personnel Policy Statement of 1991, stated that the "fact that such provisions were not formally incorporated into the Bank's practice [earlier] is a reflection of the insufficiency of the Bank's expression of pertinent obligation, not of the absence of such obligation." 80

\subsection{Jurisdiction}

\subsubsection{Admissibility ratione temporis}

The Statute fixes a 90-day period for the filing of applications. The Tribunal has also opened the door to "continuing causes of action", otherwise timebarred, that may be deemed to arise anew periodically, as in the case of reimbursements for taxes paid each year on Bank salaries ${ }^{81}$ (each tax payment giving rise to "a distinct cause of action" 82 ) or the annual dependency allowance wherein each non-payment creates a cause of action ${ }^{83}$. A contested regulation may also be challenged, not just when it is issued but likewise when it is applied to a particular person and thus infringes his rights, ${ }^{84}$ i.e., which thus constitutes "a specific, personalized and definitive rejection" of the applicants' claims. ${ }^{85}$ The Tribunal has also held that the filing period does not run until a final decision has been made by the Bank ${ }^{86}$ However, the Tribunal has rejected attempts by parties to revive time-barred cases - asking the Bank to review the case and founding the jurisdiction of the Tribunal upon the refusal of that reconsideration. $^{87}$

Finally the Tribunal has invoked the 'exceptional circumstances' clause in the Statute which allows cases to be filed beyond the 90-day limit. In the very

\footnotetext{
${ }^{79}$ Mesch and Siy, Decision No.2 [1994], 1 ADBAT Rep. 21, 31.

${ }^{80}$ Lindsey, Decision No.1 [1992], 1 ADBAT Rep.1, 4.

${ }^{81}$ Mesch and Siy (No. 3), Decision No.18 [1996], 2 ADBAT Rep.117, 129.

${ }^{82}$ Mesch and Siy, Decision No.2 [1994], 1 ADBAT Rep.21, 32.

${ }^{83}$ Amora, Decision No.24 [1997], 3 ADBAT Rep.1, 11.

${ }^{84}$ Viswanathan, Decision No.12 [1996], 2 ADBAT Rep.35, 36 (severance pay, also at the time of separation, when severance pay was payable; Mesch and Siy (No. 3), Decision No.18 [1996],
}

2 ADBAT Rep.117, 126 (tax reimbursement, at time the Bank actually refused to reimburse taxes); and Amora, Decision No.24 [1997], 3 ADBAT Rep.1 (retirement benefits, upon retirement, when the entitlement became payable).

${ }^{85}$ Mesch and Siy (No.4), Decision No.35 [1997], 3 ADBAT Rep.71, 73.

${ }^{86}$ Amora, Decision No.24 [1997], 3 ADBAT Rep.1, 13.

${ }^{87}$ Nelson, Decision No.7 [1995], 1 ADBAT Rep.77, 84; Behuria, Decision No.8 [1995], 1

ADBAT Rep.89, 96. 
first case filed before the Tribunal, the application could not be filed within that period because the then newly established Tribunal had not yet become fully operational and had yet to adopt its Rules of Procedure. However, the Tribunal has strictly defined 'exceptional circumstances' as "those which prevent compliance with the requirements as to time and internal remedies" and does not refer to the extraordinary nature of the grievance ${ }^{88}$ or the "gravity of the injury per se" or the futility of further exhausting internal remedies. ${ }^{89}$

\subsubsection{Admissibility ratione materiae}

Exhaustion of internal remedies has been considered as a requirement ratione materiae. No claim may be raised before the Tribunal unless either the claim itself was properly raised, ${ }^{90}$ or the material had been made available, ${ }^{91}$ during in the internal appeals. Its rationale was explained thus:

"Internal remedies enable each party to better appreciate the position of the other; they provide the administration with an opportunity to ascertain the causes of an alleged grievance and to arrive at a settlement; and internal appeal bodies which are generally more familiar with organizational factors may also elicit material evidence which might not otherwise be avilable to the Tribunal. There must be cogent reasons for dispensing with internal remedies. ${ }^{\text {"92 }}$

Also, It has further rejected as inadmissible ratione materiae cases where the party failed to meet the filing-periods before those internal grievance bodies. ${ }^{93}$

The Tribunal hears only cases that arise from non-observance of the contract of employment, and has held as inadmissible cases that arise from other sources. ${ }^{94}$ The claim must also pertain to the Applicant's own rights and benefits. ${ }^{95}$ and not to another person's.

\subsection{Justiceability of discretionary power}

\subsubsection{Reviewability of the exercise of discretionary power}

The Tribunal, at the outset, recognized the "broad discretion [of the Bank] to determine [its] policy ... and its operational needs".

\footnotetext{
${ }^{88}$ Nelson, Decision No.7 [1995], 1 ADBAT Rep.77, 85.

${ }^{89}$ Mesch and Siy (No.3), Decision No.18 [1996], 2 ADBAT Rep.117, 128.

${ }^{90}$ Isip, Decision No.9 [1996], 2 ADBAT Rep.1, 15.

${ }^{91}$ Wilkinson, Decision No.10 [1996], 2 ADBAT Rep.19, 22.

${ }^{92}$ Mesch and Siy (No.3), Decision No.18 [1996], 2 ADBAT Rep.117, 127.

${ }^{93}$ Behuria, Decision No.8 [1995], 1 ADBAT Rep.89, 96.

${ }^{94}$ Nelson, Decision No.7 [1995], 1 ADBAT Rep.77, 86.

${ }^{95}$ Carolina Chan, Decision No.21 [1996], 2 ADBAT Rep.157, 157 and 160.
} 
"In some respects this discretion is absolute; in others it is not. In case of dispute, the determination of the reviewability of the discretion falls within the jurisdiction of the Administrative Tribunal. Like any other judicial body, it possesses the competence to determine its own competence. In general, reviewable discretions are those the exercise of which can have an effect upon the position of staff members in their individual relationships with the Bank." 96

What is the extent of judicial review over managerial discretion? The Tribunal recognized that the power to review "does not mean that the Tribunal can substitute its discretion for that of the management".

"The Tribunal cannot say that the substance of a policy decision is sound or unsound. It can only say that the decision has or has not been reached by the proper processes, or that the decision either is or is not arbitrary, discriminatory or improperly motivated, or that it is one that could or could not reasonably have been taken on the basis of facts accurately gathered and properly weighed." 97

This view affects the nature of the relief available from the Tribunal in these cases. The Statute provides that the following remedies are available: rescission of the decision contested, or specific performance of the obligation invoked, or, in lieu of specific performance and at the option of the Bank, payment of compensation. ${ }^{98}$ The Tribunal, citing World Bank precedent, ${ }^{99}$ has interpreted this to authorize the Tribunal to fix an amount of compensation without ordering either rescission or specific performance. Where the decision contested, however, is discretionary in character (e.g., a decision not to promote an officer), the Tribunal is not itself entitled to exercise that discretion (e.g., to promote the officer). "Such a direction would constitute an affirmative exercise by the Tribunal of a discretionary power belonging to the Bank and a substitution of the Tribunal's own judgment for that of the Bank". ${ }^{100}$ Instead, the Tribunal is limited to setting aside the defective decision and, where applicable, remand the issue to the Bank for proper disposition. ${ }^{101}$

\footnotetext{
${ }^{96}$ Lindsey, Decision No.1 [1992], 1 ADBAT Rep.1, 4.

${ }^{97}$ Lindsey, Decision No. 1 [1992], 1 ADBAT Rep.1, 5.

${ }^{98}$ Statute, Art.X para.1.

${ }^{99}$ Lindsey, Decision No.1 [1992], 1 ADBAT Rep.1, 17 (citing Skandera, WBAT Rep.1981, Decision No.2, para. 29; Buranavanichkit, WBAT Rep.1982, Decision No.7, para. 30; Broemser, WBAT Rep.1985, Decision No.27, para. 40.).

${ }^{100}$ Tay Sin Yan, Decision No.3 [1994], 1 ADBAT Rep.35, 46.

${ }^{101}$ Ibid. at 35 (setting aside a performance evaluation and the consequent denial of a promotion, and ordering a fresh evaluation on which the promotion may, or may not, be granted); Isip, Decision No.9 [1996], 2 ADBAT Rep.1; Chan (No. 2), Decision No.36 [1997], 3 ADBAT Rep.111.
} 


\subsubsection{Reviewability of decisions by the Board of Directors}

The Tribunal asserted its power to review decisions by one of the Bank's governing bodies, the Board of Directors. It stated that "fundamental and essential conditions" limits the powers of the governing bodies of every international organization, and that the Bank's Board of Governors and Board of Directors are subject to that limitation. The case pertained to the Bank's reinterpretation of its duty of equal treatment to apply to before-tax salaries:

"[W] hen the Statute of the Tribunal was adopted, that limitation already existed: it was not one imposed or deemed to have been imposed by the Statute. The Tribunal was given jurisdiction in respect of complaints by staff members alleging non-observance of their contracts of employment and terms of appointment. That Statute does not prescribe any pertinent exception or qualification in respect of the jurisdiction of the Tribunal ...." ${ }^{102}$

The Tribunal was silent on the question of whether the international organization may exclude itself from that rule via a provision in its charter. ${ }^{103} \mathrm{~A}$ dissenting opinion lamented that the Bank's re-interpretation, coming at the heels of the Tribunal's decision holding that the norm of equality entailed tax reimbursements, was "a blatant disregard of the Tribunal's authority". ${ }^{104}$

\subsubsection{Reviewability of disciplinary decisions}

In disciplinary cases, is the Tribunal's task limited to reviewing the regularity of the proceedings below, or can the Tribunal inquire into the substantive findings? The Tribunal, citing precedent before the World Bank tribunal, ${ }^{105}$ has inquired beyond the question procedural regularity and examined "(i) the existence of the facts, (ii) whether they legally amount to misconduct, (iii) whether the sanction imposed is provided for [by] law ..., (iv) whether the sanction is not significantly disproportionate to the offence, and (v) whether the requirements of due process were observed". ${ }^{106}$

\subsubsection{Substantive limits on discretion}

Apart from constraints flowing from "fundamental and essential conditions", the Bank's power to amend "non-fundamental and non-essential condi-

\footnotetext{
${ }^{102}$ Mesch and Siy (No.3), Decision No.18 [1996], 2 ADBAT Rep.117, 125.

${ }^{103}$ Ibid.

${ }^{104}$ Mesch and Siy (No.4), STERN dissenting, Decision No.35 [1997], 3 ADBAT Rep.71.

${ }^{105}$ Carew, WBAT Rep.1995, Decision No.142 (see para. 32).

${ }^{106}$ Zaidi, Decision No.17 [1996], 2 ADBAT Rep.89, 92; see also Chaudhry, Decision No.23 [1996],

2 ADBAT Rep.171.
} 
tions" 107 of employment are further subject to substantive and procedural restrictions.

The Tribunal has decided several claims on various grounds of discrimination. The first cases arose on the question of tax reimbursement and what equal treatment meant as between staff whose home governments had waived their power to tax their Bank salaries, and staff whose governments had not done so.

The Tribunal first held that the norm of equality must be applied to "net benefits, after tax", i.e., effective and not merely formal equality:

"The Tribunal observes that the comparison of compensation levels on the practical plane necessarily involves a consideration of the net benefits, after tax if any, to the recipient. Therefore, it cannot be said that a given salary which, in the hands of one recipient, is taxable is the same as an identical figure which, in the hands of another, is not. Accordingly, the failure to consider the incidence of taxation is inconsistent with the principle of 'equal compensation for comparable work'." 108

The Bank subsequently adopted a resolution "reaffirm[ing] its longstanding practice of no reimbursement" and declared that the principle of equal treatment shall be applied to before-tax salaries. The matter was brought to the Tribunal, which found that the resolution was a valid unilateral act by the Bank and that the Bank's duty of tax reimbursement was not a "fundamental and essential condition of employment" which can be changed only with the consent of all parties. ${ }^{109}$ In that decision, the Tribunal interpreted the norm of equality as well:

"In the strict sense equal compensation for equal work means equal pay for work of equal value; and then the application of the principle involves only a consideration of the value of the work to the employer. .... Equally, the personal circumstances of the employee are irrelevant: thus the fact that, due to some physical disability, he has to incur additional expenses in coming to work does not entitle an employee to additional pay, because the value of his work to his employer remains the same. The employer's obligation to treat his employees equally does not extend to remedying discrepancies created by the conduct of the State of which the employee is a citizen. ${ }^{110}$ (emphasis supplied)

A dissenting opinion states that non-discrimination necesssarily "mean[s] not only purely nominal equality, but also effective equality", as supported by past rulings and practices of other international organizations. ${ }^{111}$

Another classification challenged before the Tribunal was discrimination on the basis of nationality. Filipino professional staff challenged their exclusion

\footnotetext{
${ }^{107}$ Mesch and Siy (No.4), Decision No.35 [1997], 3 ADBAT Rep.71, 89.

${ }^{108}$ Mesch and Siy, Decision No.2 [1994], 1 ADBAT Rep.21, 30.

${ }^{109}$ Mesch and Siy (No.4), Decision No. 35 [1997], 3 ADBAT Rep. 71.

${ }^{110}$ Ibid. at 71,84 .

${ }^{111}$ Ibid. at 93.
} 
from certain employment benefits, i.e., education grant, home leave, force majeure protection and severance pay. The Bank alleged that the exclusion was not nationality-based but was based either on place of service (as regards education and home leave benefits), on the extent of protection from political disturbances required (as regards force majeure) and, on the place of retirement (as regards severance pay). The Tribunal also clarified its earlier statement in the tax reimbursement cases that "equal pay for work of equal value" involved "only a consideration of the 'value' of the work to the employer", and that accordingly "the personal circumstances of the employee are irrelevant", e.g., the fact that "due to some physical disability, he has to incur additional expenses coming to work does not entitle [him] to additional pay, because the value of his work to his employer remains the same". ${ }^{112}$ The Tribunal held that, as regards employment benefits, the personal circumstances of the staff member were most relevant, e.g., spousal allowances, dependency allowances and education grants for children necessarily depend on whether the staff member has a spouse, dependents or children in school. ${ }^{113}$ The test of discriminatory treatment in this regard therefore is whether the "differences in personal circumstances arising from the [expatriate status of staff members] vis-à-vis their non-expatriate colleagues - constitute a rational basis" for exclusion.

Finally, a third criterion of classification brought before the Tribunal was gender. A woman challenged the Bank's decision not to 'regularize' her appoint, allowing her initial three-year appointment to expire, contending inter alia that her male supervisors, due to cultural differences, apparently mistook her assertiveness for belligerence. The Tribunal found no evidence of genderdiscrimination, although it awarded some compensation for procedural infractions. ${ }^{114}$

${ }^{112}$ Citing Mesch and Siy (No. 4), Decision No. 35 [1997], 3 ADBAT Rep. 71, at 84.

${ }^{113}$ De Armas, et al., Decision No. 39 [1998], 4 ADBAT Rep. 9.

${ }^{114}$ Alexander, Decision No.40 [1998], 4 ADBAT Rep.41. 